\title{
NUMERICAL MODELING OF GROUNDWATER TO ASSESS THE IMPACT OF PROPOSED RAILWAY CONSTRUCTION ON GROUNDWATER REGIME
}

\author{
${ }^{1}$ Zinaw Dingetu SHENGA, ${ }^{2}$ Dana BAROKOVÁ, ${ }^{3}$ Andrej ŠOLTÉSZ \\ ${ }^{1,2,3}$ Department of Hydraulic Engineering, Faculty of Civil Engineering \\ Slovak University of Technology in Bratislava, Slovakia \\ ${ }^{1}$ zinaw.shenga@stuba.sk, ${ }^{2}$ dana.barokova@stuba.sk, ${ }^{3}$ andrej.soltesz@stuba.sk
}

Received 1 January 2018; accepted 22 May 2018

\begin{abstract}
The new proposed railway network in the city of Bratislava, which is supposed to be connected to the airport, is an integral part of Trans-European Network for Transport .Certain section of the planned railway should be constructed along Carpathian Mountains through underground tunnels. However, the construction of this underground tunnel will adversely affect the groundwater flow regime. Therefore, it was necessary to establish a $2 \mathrm{D}$ finite element numerical model to evaluate the implementation of this railway tunnel on the groundwater regime as well as means of technical measures to reduce the impacts. The paper presents the model result, analyses, prognosis as well as possible methods to control the groundwater level regime in the aquifer that could be affected by the railway tunnel construction.
\end{abstract}

Keywords: Numerical simulation, Groundwater flow, Groundwater/surface water interaction, Triwaco software package, Underground wall

\section{Introduction}

The Trans-European Transport Network (TEN-T) is aimed to improve connections between different nodes of transport network to facilitate the mobility of goods and passengers with in the European Union [1]. The project includes all modes of transport, namely: road, rail, maritime, inland waterways, air, logistics, co-modality and innovation [1], [2]. The interconnection of the railway corridor in a City of Bratislava, which consists construction of railway line networks in the city is one part of the projects of TEN-T. The railway network is supposed to be connected to the Bratislava airport as well as to Petržalka across Danube River [3]. However, certain part of this 
railway network is planned to be constructed along Carpathian Mountains passing through underground tunnel. The first section (Bratislava Predmestie - Bratislava Filiálka) of the route, as it is shown in Fig. 1, is designed to submerge gradually below the terrain [4]. This underground structure consists deep excavation, which is protected by sheet pile and sealing walls. The other railway section is planned to pass under Danube River bed and then connected to the existing railway network on the side of Petržalka, but on ground surface.

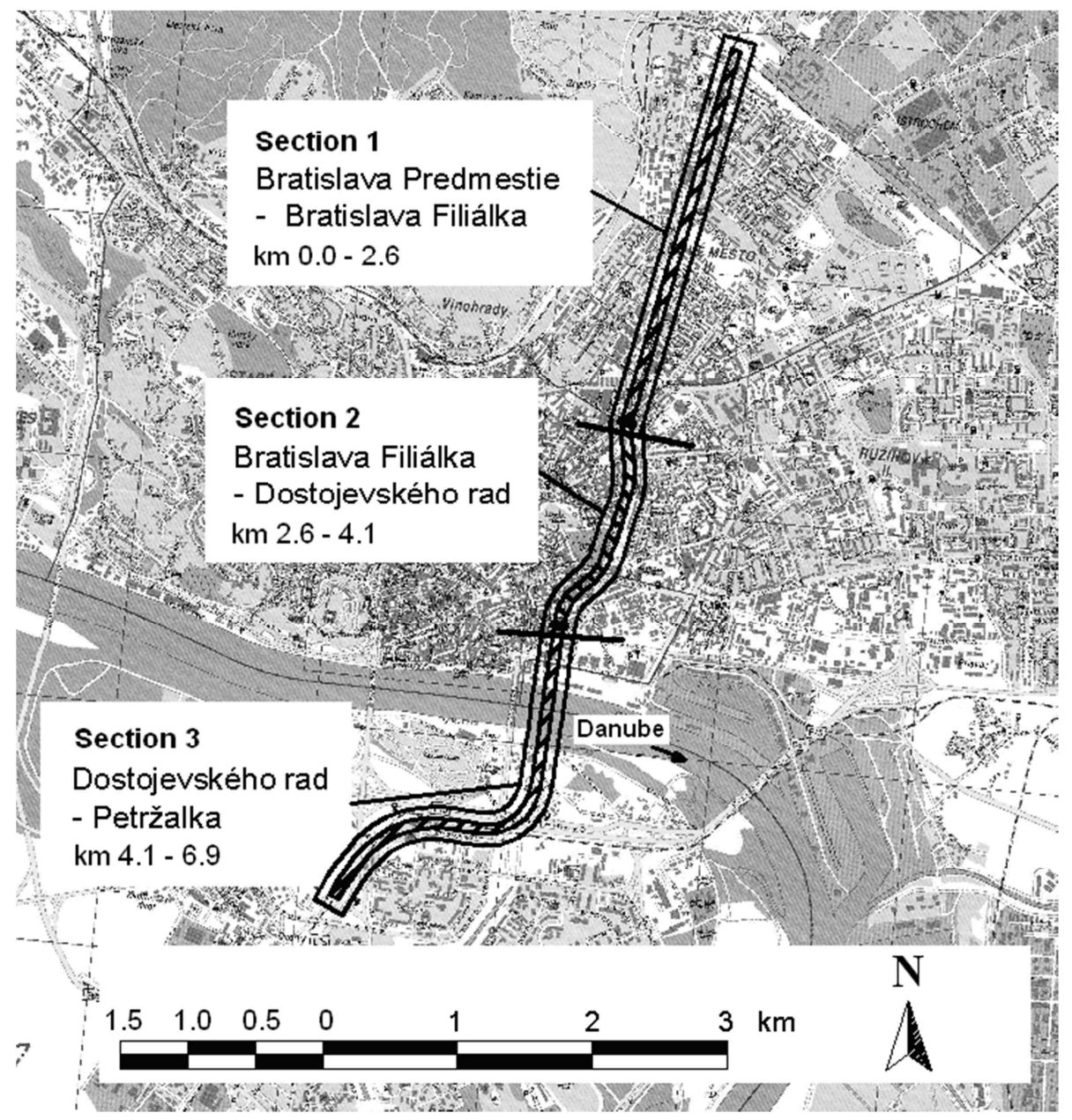

Fig. 1. General overview of the proposed TEN-T railway corridor section in Bratislava [3]

The proposed underground railway route, the section between Bratislava Predmestie and Bratislava Filiálka railway station, is located in the aquifer at a depth of more than $22 \mathrm{~m}$ below the terrain (see Fig. 2). The construction of the route includes sheet piles and sealing wall of about $2 \mathrm{~km}$ long which will have some negative impacts on the 
groundwater flow and regime. The main goal of this paper is to assess the impact of the designed underground railway route on the regime of groundwater and propose proper technical measures to minimize the negative impacts. To address this challenge, the Triwaco software package that uses finite element method for groundwater modeling is applied.

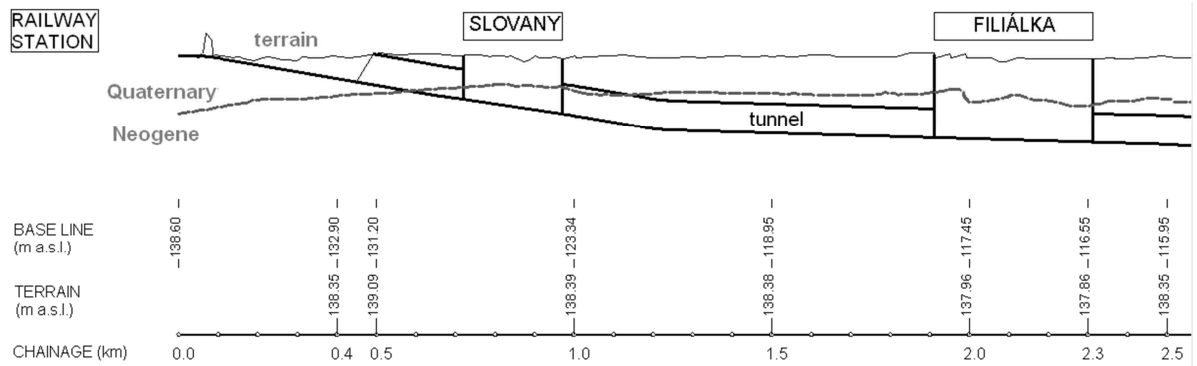

Fig. 2. Longitudinal cross-section of the designed route (section 1); the foundation pit is supposed to be located at $\mathrm{km} 0.1-2.33$ [3]

\section{Material and method}

\subsection{Material}

The railway route Bratislava Predmestie - Bratislava Petržalka passes directly through the residential areas of Bratislava. According to the geomorphological division [3] the region in question lies on the boundary of the Danubian Plain and the Small Carpathians. The altitude in the surroundings of the region in question ranges from 134 to 140 meters above sea level.

The total area of the territory which is under the assessment is approximately $60 \mathrm{~km}^{2}$. The Slovak Hydro-Meteorological Institute (SHMI) [4] archive data about groundwater level recorded in the observation wells are used to create the boundary conditions of the domain of the model. Data about precipitation is also obtained from SHMI too.

Geologically, the area of interest is classified under Danube Lowlands. The sub-soil is composed of Paleozoic, Neogene and Quaternary minerals. With regard to the depth of the track alignment, more attention is given only to the quaternary and Neogene sediments. The Neogene sediments do not appear directly on the surface, but they are covered by fluvial quaternary sediments. The fluvial gravel sediments in the region are 10 to $17 \mathrm{~m}$ deep. The top layers of gravel are covered across the entire region by a discontinuous, 1 to $3 \mathrm{~m}$ deep layer of fluvial clays and sands. The average hydraulic conductivity of the Quaternary gravel aquifer sediments is approximately $10^{-3} \mathrm{~m} \cdot \mathrm{s}^{-1}$. Based on these values, the aquifer may be considered as an environment with a relatively high permeability.

The activities of the groundwater (i.e. groundwater creation, shaping and dynamics [5]) in the area of study are predominately governed by Danube River. Water from the 
river percolates to the quaternary gravel alluvial on both sides of the river bed. The groundwater level in the area of interest ranges from 3 to $8 \mathrm{~m}$ below ground level based on the rise or fall in water level of Danube River. Currently, the Danube water level is affected by the Gabčíkovo Water Structure (GWS) - its backwater reaches above the region under study.

The groundwater table regime in the region is stable; hence, the differences between the average and maximum groundwater levels are small (between 0.13 to $0.25 \mathrm{~m}$ ). The value of the so-called effective precipitation was also used as input parameter for the model; it was determined as the difference between total precipitation and actual evapotranspiration in the region [6]. The Danube River and also the Rača Stream water levels were available from the SHMI. Additionally, figures for average monthly groundwater off takes, which were processed for the long-term average values are obtained from the same institute.

The results of the indicative engineering-geological survey obtained from the available archive geological background documents [7], complemented by knowledge from the exploratory drilling and terrain survey performed for the TEN-T project, also by background documents from the SHMU [6], archival works of the State Geological Institute of Dionýz Štúr (SGIDŠ) and Dopravoprojekt Bratislava Inc. were processed and used for digitization of the hydraulic conductivity $\left(\mathrm{m}^{\mathrm{d}} \mathrm{d}^{-1}\right)$ ), for creating the map of the terrain, the map of the overlying layers interface and the map of the quaternary basis, i.e. the Quaternary and Neogene interfaces.

\subsection{Methods}

The Triwaco program [8] was used for numerical simulation of the groundwater flow. This simulation package for groundwater is a program system for a quasi-threedimensional simulation of groundwater flow, based on the Finite Element Method (FEM) [9], [10]. The differential equations of filtration plane groundwater flow follow from Darcy's Law and from the continuity equation [11], [12]. On the basis of the Dupuit-Forchheimer assumption, the equation for steady groundwater flow for each aquifer or its part can be written in the following form [13], [14]:

$$
\frac{\partial}{\partial x}\left[T_{x x} \frac{\partial h}{\partial x}+T_{x y} \frac{\partial h}{\partial y}\right]+\frac{\partial}{\partial y}\left[T_{y x} \frac{\partial h}{\partial x}+T_{y y} \frac{\partial h}{\partial y}\right]+q=0
$$

where $T_{x x}, T_{x y}, T_{y x}, T_{y y}$ are transmissivity tensors $\left[\mathrm{m}^{2} . \mathrm{s}^{-1}\right] ; q$ is specific discharge $\left[\mathrm{m}^{3} \cdot \mathrm{m}^{-2} \cdot \mathrm{s}^{-1}\right]$ and $h$ is hydraulic head $[\mathrm{m}]$.

Boundary conditions have to be given if the system of equations is to have a solution. These may be of three types:

1. stable (i.e. the Dirichlet) boundary condition (of the first type);

2. unstable (i.e. the Neumann) boundary condition (of the second type); or

3. mixed (i.e. the Cauchy) boundary condition (of the third type) [2], [15].

For this specific work, the groundwater heads in SHMI observation wells were predominantly used as a first type boundary condition. Inflow from the slopes of the 
Small Carpathians in the west and north-western of the boundary of the model was used as Neumann boundary condition. However, the recorded water stage in Danube River is used as internal boundary condition to set the limits of the groundwater head in the domain.

The model conceptualization, which includes description of the model composition, the physical phenomenon and the relevant aquifer properties are performed with the mentioned Triwaco software. That means, the limits of the piezometric heads in the domain are created based on the physical, hydrological, geological and hydrogeological data obtained from different companies and institutes. Then conceptual model is mathematically represented in the form of numerical schemes and discrete solution.

The Triwaco [8] simulation model based on FEM was used to simulate the groundwater flow. The FEM is more practical than other methods as it is geometrically flexible and it has ability to precisely apply the appropriate boundary conditions on complex domain [16]. Using the numerical models, the piezometric head was simulated by an approximation of the governing equation at specific locations. The head was calculated at discrete points in space and for specific values of time [8]. The initial piezometric heads were displayed as a contour map from the data imported. When modeling the sealing wall, the elements were gradually downsized for localization of the wall's property. The mesh consists of elements in the range 2 to $150 \mathrm{~m}$ as it is shown in Fig. 3.

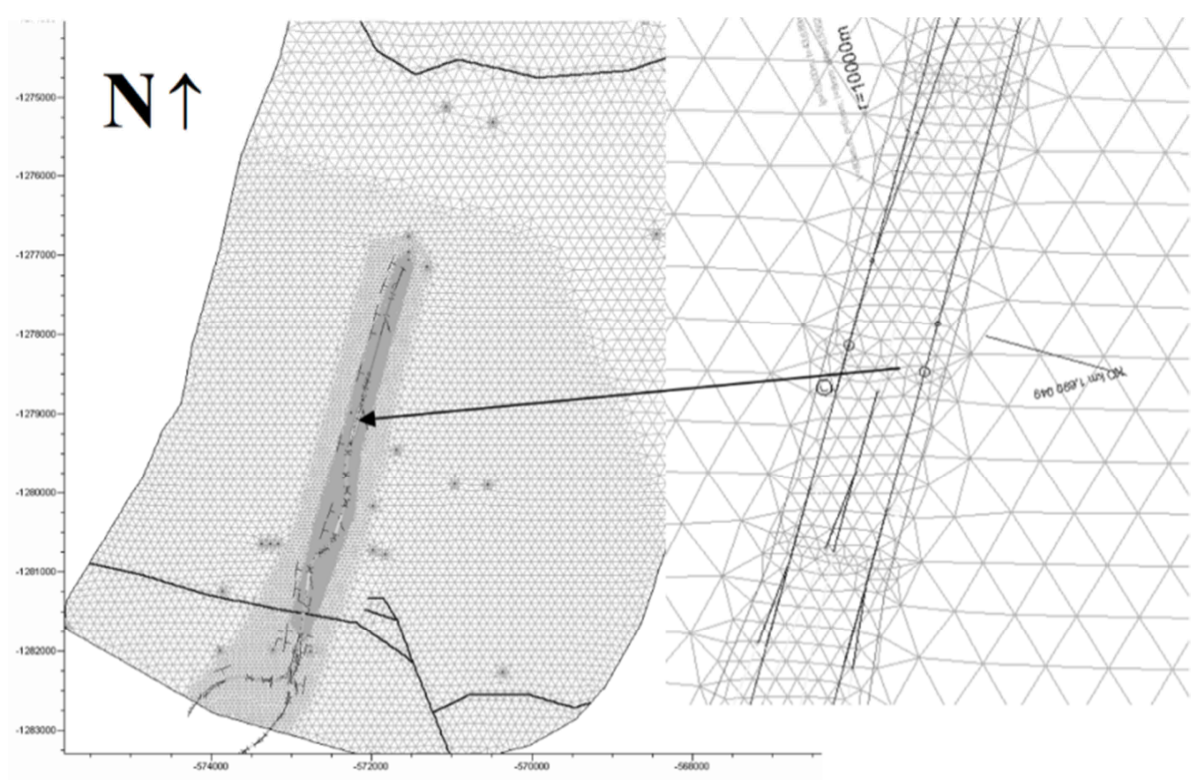

Fig. 3. Details of the finite element mesh

The measured groundwater heads in SHMI observation wells were used to calibrate the simulated results. The calibration of the model was focused on adjustment of hydraulic and hydrogeological parameters in order to fit the simulated groundwater 
head with field measured values. The adjusted parameters were: hydraulic conductivity, drainage and infiltration resistance of river beds [8] and inflow from the slopes of the Small Carpathians in the west and north-western parts of the region. The differences between the measured and the calculated groundwater level values in the area of interest were up to $\pm 0.50 \mathrm{~m}$ after calibration of the model.

It is clear that there is a difference between the measured and calculated groundwater head. However, due to dispersion between the maximum and minimum groundwater head, the differences are believed to be acceptable.

\section{Result and discussions}

After calibration of the model, the next step was investigating the groundwater flow direction. The groundwater flow direction and level in the area of interest is highly influenced by the gradient of the terrain as well as the impermeable layers of the subsoil. The modeling result illustrated, groundwater flows from Small Carpathian Mountains towards south-eastern of the area of interest (Fig. 4).

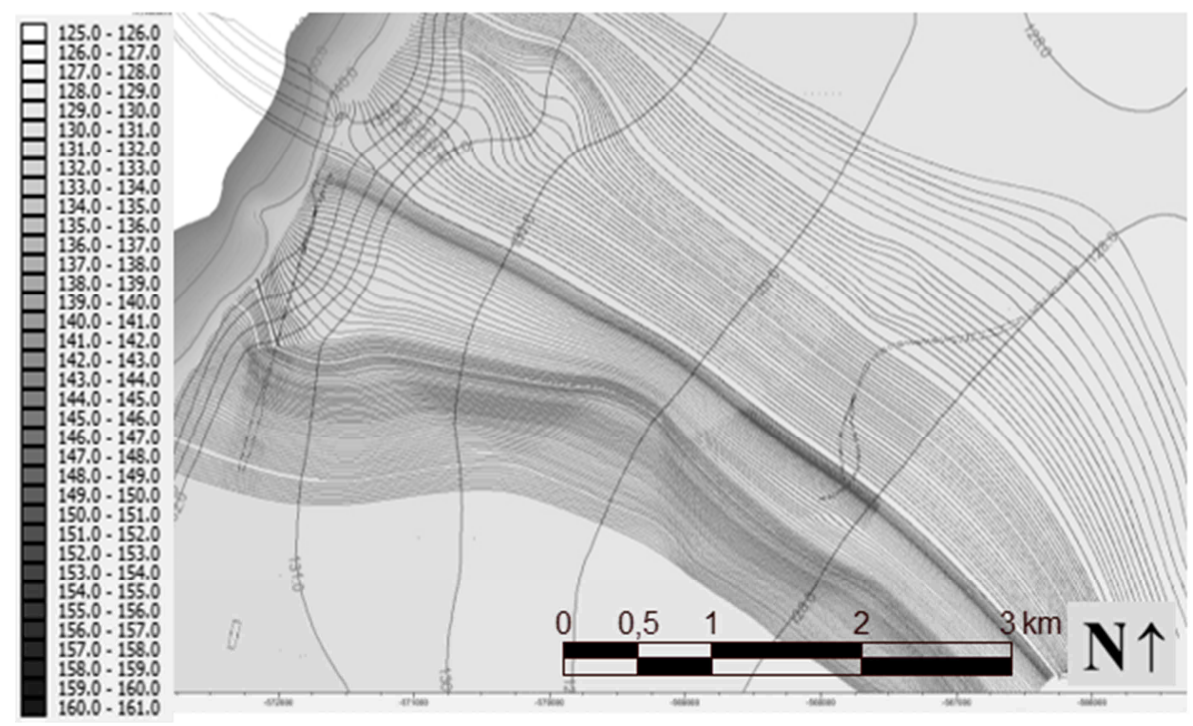

Fig. 4. Simulated groundwater flow direction at the present time

The proposed water-tight foundation pit, which is $2 \mathrm{~km}$ long and 12-60 m wide is supposed to be constructed at the mentioned area. Obviously, the construction will have negative effect on groundwater level as well as on flow direction. Thus, it is essential to introduce further variant about the structure in the modeling system to assess the negative impacts. However, the Triwaco model is supposed to simulate groundwater flow only through porous media. But, it is possible to design the water-tight foundation pit as media with a very low hydraulic conductivity (i.e. the value to be in the order of hundredths to thousands m. $\mathrm{d}^{-1}$ ). After introducing the variant into the model system, the 
result indicated that the groundwater level increased on one side of the foundation pit (Fig. 5). This implies that, there is a backwater on the western part due to the structure and the water flows around the whole length of the foundation pit (Fig. 6). In another word, on the western side of the structure the groundwater level is increased up to $2.4 \mathrm{~m}$, whereas there is a decrease in a groundwater level on the eastern side up to $0.6 \mathrm{~m}$.

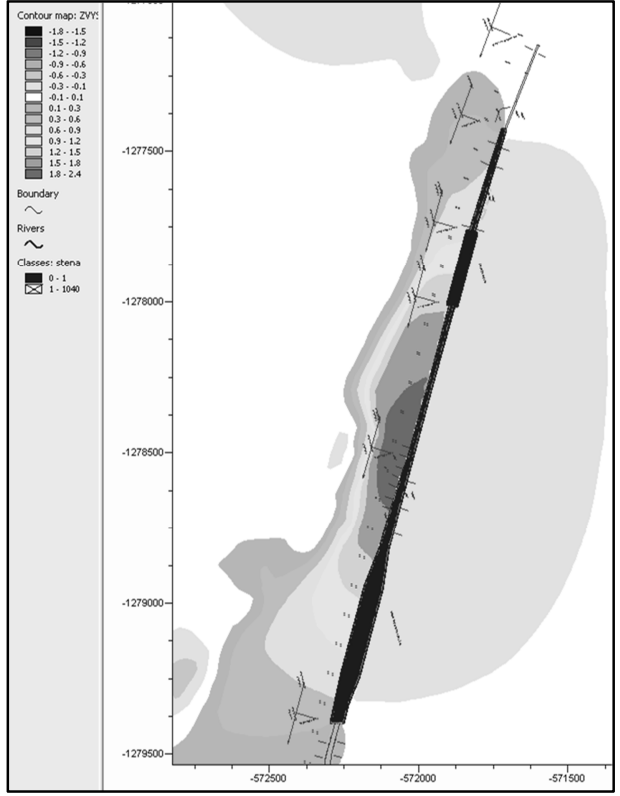

Fig. 5. Expected increase in ground water level after construction of the sealing wall

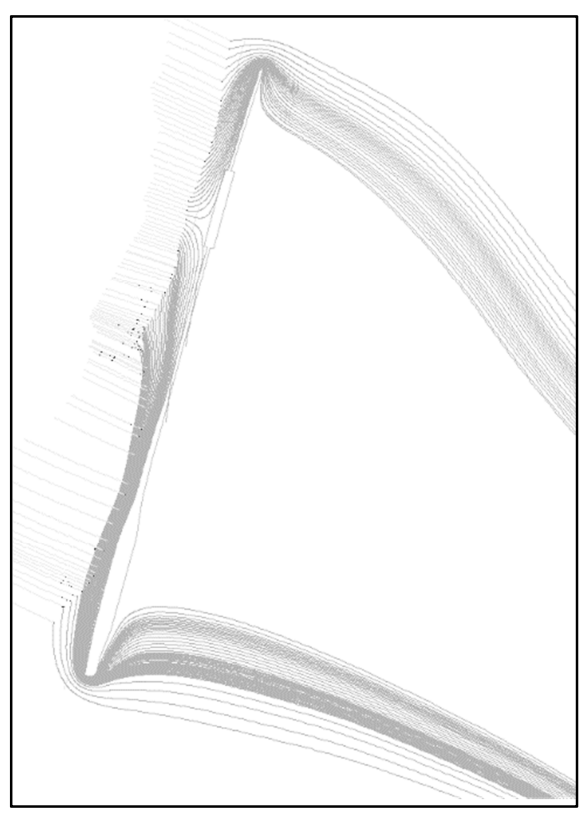

Fig. 6. Simulated ground water flow direction after construction of the sealing wall

In order to reduce the negative impacts, it is more convenient to create some openings at reasonable location in the sealing wall. The designed opening will be used to allow groundwater flow from the western side of the sealing wall to the eastern side across the proposed railway route. The proposed solution can be presented in two variants, i.e. 5 openings at a distance of $180 \mathrm{~m}$ or 9 openings at a distance of $100 \mathrm{~m}$ as it is shown in Fig. 7 and Fig. 8. The designed openings could be constructed from very permeable material or could be kept empty. The simulation was carried out by considering $2 \times 2 \mathrm{~m}$ wide rectangular openings with assumed hydraulic conductivity in the order of $10^{-3} \mathrm{~m} \cdot \mathrm{s}^{-1}$.

The simulation results demonstrated that this design would reduce the groundwater level by 1.3-1.6 m compared with the design of the sealing wall without openings. The groundwater level can be decreased by $1.3 \mathrm{~m}$ by designing the first variant (i.e. 5 openings). However, the simulation result of the second variant (i.e. 9 openings) indicated that the groundwater level could be decreased by $1.6 \mathrm{~m}$. Though, the decrease 
in groundwater level using either 5 or 9 openings is almost similar, but it could be more convenient to choose 9 openings than 5 to assure better safety. The increase in the groundwater level after implementing these measures compared with the present state will range only from 0.4 to $0.7 \mathrm{~m}$ (Fig. 7), i.e. 5.7 to $6 \mathrm{~m}$ below ground level, which is acceptable.

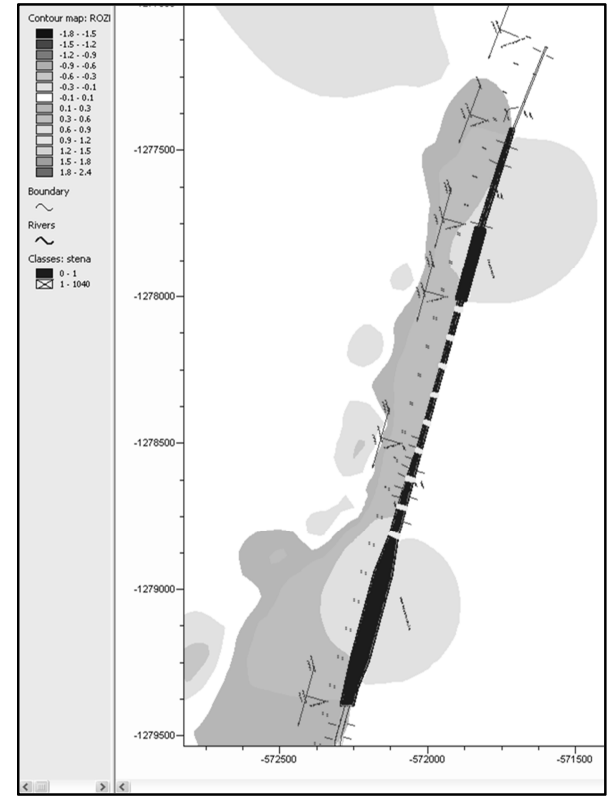

Fig. 7. Expected decrease in ground water level with 9 openings in the sealing wall

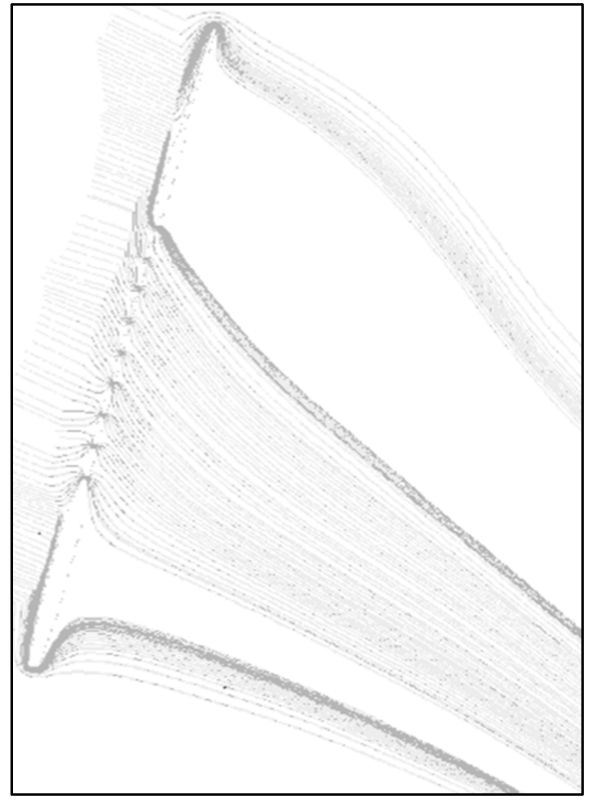

Fig. 8. Simulated ground water flow direction with 9 openings in the sealing wall

\section{Conclusions}

The paper presented results of numerical modeling that was carried out in order to investigate the impact of underground construction (railway tunnel as a part of TEN-T) on groundwater regime in its surroundings. The analysis, prognosis as well as the possible alternatives to control the groundwater level regime in the aquifer that could be affected by the railway tunnel construction is presented. The modeling result showed that the part of the proposed railway route, which is supposed to be constructed in the tunnel system, could adversely affect both groundwater level and flow direction; specially the section which is designed to be located in the tunnel system.

In order to minimize the negative impact of the underground construction, two technical measures are considered, i.e. construction of 5 or 9 openings in the sealing wall. The proposed technical measure is believed to be acceptable as the rise in 
groundwater level is minimized to reasonable level (i.e. groundwater level could be decreased by $1.3 \mathrm{~m}$ or $1.6 \mathrm{~m}$ using 5 or 9 openings, respectively). Comparing the two alternative measures, it could be better to accept the second one (i.e. constructing 9 openings) to reduce the expected impacts of the railway construction on groundwater regime.

\section{Acknowledgements}

The contribution was developed within the frame of and based on the financial support of the APVV-14-0735 project 'New possibilities for the use of drainage channels, taking into account the biodiversity in a landscape'.

The contribution was also developed within the frame and based on the financial support of the APVV-15-0489 project 'Analysis of droughts by multi-criterial statistical methods and data mining from the viewpoint of preventive structures in a landscape'.

\section{References}

[1] Infrastructure-TEN-T-Connecting Europe, https://ec.europa.eu/transport/modes/rail_en, (last visited 26 December 2017).

[2] Burski Z., Mijalska-Szewczak I., Wasilewski J., Szczepanik M. Evaluation of energy consumption of vehicles in EU Trans-European Transport Network, Transportation Research Part A: Policy and Practice, Vol. 92, 2016. pp. 120-130.

[3] Škvarka J., Kupka Š., Takáčová M., Šikula G. Study of railway connection in the City of Bratislava, (in Slovak). Ekogeos Ltd, Bratislava, 2007.

[4] Dopravo-projekt Bratislava Ltd Company, Background materials Bratislava, (in Slovak) Slovak Hydro-Meteorogical Institute, 2007, www.shmu.sk, (last visited 20 October 2007).

[5] Sandro R., Louati S., Bendjoudi H., de Marsily G. Modeling of transient groundwater flow, pollutant transport, and biodegradation in an aquifer with large hydraulic head variations, Hydrogeology Journal, Vol. 22, No. 4, 2014, pp. 943-956.

[6] Hydrological data on the groundwater and surface water levels from the basic, (in Slovak) Slovak Hydro-Meteorological Institute observation networks, Bratislava, 2015, www.shmu.sk, (last visited 20 March 2016).

[7] Archive works of the Geofond Department at SGIDŠ Bratislava, 2007.

[8] Haskoning R. Triwaco a simulation package for groundwater, Version 3. 0 internal release Royal Haskoning Division Water, Rotterdam, Netherlands, 2002.

[9] Bear J. Hydraulics of groundwater, Dover Publication Inc. 1979.

[10] Andrássy T., Baroková D. Numerical modeling of groundwater flow close to drinking water resources during flood events, Pollack Periodica, Vol. 11, No. 1, 2016, pp. 43-54.

[11] Zaadnoordijk W. J. Simulating piecewise-linear surface water and ground water interactions with MODFLOW, Ground Water, Vol. 47, No. 5, 2009. pp. 723-726.

[12] Kuriqi A., Ardiçlioglu M., Muceku Y. Investigation of seepage effect on river dike's stability under steady state and transient conditions, Pollack Periodica, Vol. 11, No. 2, 2016, pp. 87-104.

[13] Obergfell C., Bakker M., Zaadnoordijk W. J., Maas K. Deriving hydrogeological parameters through time series analysis of groundwater head fluctuations around well fields, Hydrogeology Journal, Vol. 21, No. 5, 2013. pp. 987-999. 
[14] Červeňanská M., Baroková D., Šoltész A. Modeling the groundwater level changes in an area of water resources operations, Pollack Periodica, Vol. 11, No. 3, 2016, pp. 83-92.

[15] Constantin A. Hydraulic simulation of water distribution network in rural area - first stage in water infrastructure improvement, International Multidisciplinary Scientific GeoConference (SGEM), Vol. 1, 2016, pp. 415-422.

[16] De Graaf E. M., van Beek R. L. P. H., Gleeson T., Moosdorf N., Schmitz O., Sutanudjaja E. H., Bierkens M. F. P. M. A global-scale two-layer transient groundwater model: Development and application to groundwater depletion, Advances in Water Resources, Vol. 102, 2017, pp. 53-67. 